\title{
Article \\ Biological Methods in Biodiesel Production and Their Environmental Impact
}

\author{
Krzysztof Biernat $^{1, * \mathbb{D}}$, Anna Matuszewska ${ }^{1}$, Izabela Samson-Bręk ${ }^{2} \mathbb{D}$ and Marlena Owczuk ${ }^{1}$ (D) \\ 1 Łukasiewicz Research Network-Automotive Industry Institute, 03-301 Warsaw, Poland; \\ anna.matuszewska@pimot.lukasiewicz.gov.pl (A.M.); marlena.owczuk@pimot.lukasiewicz.gov.pl (M.O.) \\ 2 Environmental Protection Institute-National Research Institute, 00-548 Warsaw, Poland; \\ izabela.samson-brek@ios.edu.pl \\ * Correspondence: krzysztof.biernat@pimot.lukasiewicz.gov.pl
}

check for updates

Citation: Biernat, K.; Matuszewska, A.; Samson-Bręk, I.; Owczuk, M. Biological Methods in Biodiesel Production and Their Environmental Impact. Appl. Sci. 2021, 11, 10946. https://doi.org/10.3390/ app112210946

Academic Editor: Wenming Yang

Received: 18 October 2021

Accepted: 17 November 2021

Published: 19 November 2021

Publisher's Note: MDPI stays neutral with regard to jurisdictional claims in published maps and institutional affiliations.

Copyright: (c) 2021 by the authors. Licensee MDPI, Basel, Switzerland. This article is an open access article distributed under the terms and conditions of the Creative Commons Attribution (CC BY) license (https:// creativecommons.org/licenses/by/ $4.0 /)$.

\begin{abstract}
This publication presents the technologies of enzymatic biodiesel production in comparison to the conventional methods using acid and base catalysts. Transesterification with conventional catalysts has some disadvantages, and for this reason, alternative methods of biodiesel production have been investigated. These solutions include the replacement of chemical catalysts with biological ones, which show substrate specificity in relation to fats. Replacing chemical with biological catalysts causes elimination of some disadvantages of chemical processes, for instance: high temperatures of reaction, problematic process of glycerol purification, higher alcohol-to-oil molar ratios, and soap formation. Moreover, it causes operational cost reduction and has a positive environmental impact. This is due to the lower temperature of the process, which in turn translates into lower cost of equipment and lower GHG emissions associated with the need to provide less heat to the process. The increase of biofuels' demand has led to the technology of enzymatic biodiesel production being constantly being developed. This research mainly focuses on the possibility of obtaining cheaper and more effective biocatalysts, as well as increasing the durability of enzyme immobilization on different materials.
\end{abstract}

Keywords: biodiesel; transesterification; biocatalyst; lipase; GHG emission

\section{Introduction}

In many countries, different economic crises, high pollution, and the depletion of fossil fuels are serious problems and present big challenges [1]. Given the constantly deteriorating air quality, there has been a need to find environmentally friendly solutions, including technologies of alternative fuel production. Moreover, such direction of development causes a partial move away from fossil fuels. Therefore, the development of engine fuels derived from renewable plant resources is very important. The increasing concern for environmental protection and stricter requirements in the content of harmful components in exhaust gases forces the industry to continuously develop various alternative fuels that generate less-toxic emissions.

The transport sector is one of the largest greenhouse gas emitters in the world. Decarbonizing of the transport sector is a big challenge, given the dynamic development of this sector. The International Energy Agency (IEA) predicts that the demand for mobility will increase by around $60 \%$ in 2050 [2]. On the other hand, the transport sector must reduce its greenhouse gas emissions by as much as $30 \%$ by 2030 . After the decrease in the period from 2007 to 2013, since 2014, the emissions generated in this sector have been constantly growing. The European Environment Agency predicts that greenhouse gas emissions from transport will remain rather stable until 2030 [3].

There are many different types of compounds which can be used as a substitute for conventional fuels. These compounds can be produced with the use of various methods and raw materials. In developed countries, research is focused on developing technologies 
for the production of advanced fuels (produced from various types of waste and nonfood biomass). The level of technological advancement of individual methods is different. Developed countries are beginning to withdraw from the production of so-called firstgeneration biofuels (produced from food plants) and invest money in the development of advanced biofuels (produced from non-food biomass and waste). Based on the roadmap concerning biofuels in transport in the world by 2050 [4], the most technologically advanced are technologies of the following fuels' production: ethanol from lignocellulose, methanol, fuels obtained as a result of syngas fermentation (ethanol, butanol) [5], and hydrocarbons obtained as a result of hydrotreatment of vegetable oils. There is a lack of funding for the development of new technologies in developing countries. However, global trends force the use of environmentally friendly fuels instead of fossil fuels. It means that older generation biofuels and the technology for their production are used in these countries. These fuels are most often produced from food plants (e.g., rape seed, soybean, sugar cane, and maize) and include mainly bioethanol and biodiesel.

The most common method of biodiesel production is the transesterification of fats with different alcohols and in the presence of a catalyst, influencing the course of the process and its efficiency. Chemical compounds in the form of acids or bases are the most popular catalysts used in this process. The biodiesel production methods with the use of these catalysts are well-known, and commonly used in industrial conditions, but they are not free from disadvantages and negative environmental impact. It is well-known that biodiesel as a fuel has many disadvantages (it is easy to oxidize and has a high cold filter plugging point). The raw materials for its production in North America or Europe are mainly edible oil plants, which compete with food production. On the other hand, in South America, Asia, and Indonesia, the main raw material is oil palm. It is much more efficient than other oil plants and is easy to cultivate, but unfortunately, valuable natural areas, including rainforests, are adopted for its cultivation in a barbaric manner. In order to eliminate some of the disadvantages and reduce the negative impact of biodiesel production on the environment, work is underway on the possibility of replacing chemical catalysts with biological ones. For this reason, this article presents an analysis of technological solutions for the production of biodiesel, with particular emphasis on enzymatic transesterification and environmental benefits resulting from the possibility of its use.

\section{Production of Biodiesel by Chemical Transesterification Process}

The biodiesel can be produced from different vegetable and animal fats in the conventional transesterification process (also called alcoholysis) and purification [6]. Obtained fatty acid alkyl esters (FAAE) are used as biofuels and components of diesel oil, and they are characterized by lower viscosity, higher fluidity, and better low-temperature properties in comparison with pure vegetable oil. It is commonly said that fatty acid esters are carbon-neutral fuels because the carbon in compounds emitted in the exhaust gases was captured by plants from the atmosphere via the photosynthesis process. The carriers of a new alkyl part of esters are different alcohols-commonly methanol and ethanol (used in the industrial production) [7]. Depending on which alcohols are used as a product, we obtain fatty acid methyl esters (FAME) or fatty acid ethyl esters (FAEE).

The most commonly used esters in the automotive industry are FAME. They are obtained by displacement of glycerin by methanol in a process similar to hydrolysis. The simple version of this reaction can be represented by the general equation:

$$
(\mathrm{RCO})_{3} \mathrm{O}_{3} \mathrm{R}^{\prime}+3 \mathrm{R}^{\prime \prime} \mathrm{OH}=3 \mathrm{RCOOR}{ }^{\prime \prime}+\mathrm{R}^{\prime}(\mathrm{OH})_{3}
$$

The reaction products are three moles of new fatty acid esters (biodiesel) and one mole of glycerol for one mole of completely converted triacylglycerol. The process is more complex because it consists of a number of reversible reactions that follow one another: conversions of triglycerides to diglycerides, of diglycerides to monoglycerides, and of monoglycerides to glycerol [8]. Alcoholysis reaction is an equilibrium reaction. To shift its course in favor of the products, one of the reactants (usually alcohol) should be used 
in excess. Another way is to carry out the reaction in stages and to collect a by-product (glycerol) after each stage.

The molar ratio of alcohol to triglyceride is one of the most important parameters which influence the yield of biodiesel. According to the equation, to obtain three moles of fatty acid ester and one mole of glycerin, we need three moles of alcohol and one mole of glyceride. The molar ratio depends on the type of catalyst used during the reaction. For example, to obtain the same ester yield for a given reaction time during diesel production from butanol and soybean oil, a 30:1 ratio of $\mathrm{BuOH}$ to soybean oil is required for acid catalysts and only a 6:1 ratio for alkali catalysts [7]. Higher molar ratios of substrates result in higher conversion of oil and shorten the conversion time.

Another important parameter is the type of catalyst. Transesterification can be catalyzed by different catalysts: alkalis (e.g., sodium hydroxides, potassium hydroxides, sodium and potassium alkoxides), acids (e.g., sulfuric acid, hydrochloric acid, sulfonic acids), ion exchange resins, supercritical fluids, and biocatalysts (lipases). Catalysis can be carried out both homogeneously and heterogeneously.

The triglycerides and alcohols used during alkali-catalyzed alcoholysis should be substantially anhydrous because the presence of water promotes the formation of soap. Only $0.3 \%$ of water in the mixture lowers the yield of transesterification, causes an increase in the viscosity of the reaction mixture, and hinders the separation of the biodiesel [9]. Additionally, the content of free fatty acids should be low, and if it is higher than $2 \% w / w$, the pretreatment by alcoholysis with an acid catalyst or the acid-catalyzed transesterification is recommended [10].

The time and reaction yield in the alkali-catalyzed process are varied and depend on the kind of catalyst and the process temperature. For most of the catalysts used in this transesterification, the temperature is about $60-65^{\circ} \mathrm{C}$, but there are catalysts where the temperature is higher, for example $70{ }^{\circ} \mathrm{C}$ for a $\mathrm{K}_{2} \mathrm{CO}_{3} / \mathrm{MgO}$ catalyst or $100{ }^{\circ} \mathrm{C}$ for a $\mathrm{KOH} / \mathrm{MgO}$ catalyst. The reaction time is more varied and ranges from $1 \mathrm{~h}$ (for, e.g., $\mathrm{NaOH}$, $\mathrm{Na} / \mathrm{NaOH}, \mathrm{LiNO}_{3} / \mathrm{Al}_{2} \mathrm{O}_{2}$ ) to even 8-9 h (for, e.g., $\mathrm{KI} / \mathrm{SiO}, \mathrm{Al}_{2} \mathrm{O}_{3} / \mathrm{KI}, \mathrm{ZnO} / \mathrm{KF}$ ) [11]. The yield of alcoholysis depends on the kind of catalyst. Authors of [12] investigated the effects of four alkaline catalysts: $\mathrm{NaOH}, \mathrm{KOH}, \mathrm{CH}_{3} \mathrm{Ona}$, and $\mathrm{CH}_{3} \mathrm{OK}$. They noted that the process yield for the sodium or potassium methoxide (99.33 wt.\% and $98.46 \mathrm{wt} . \%$, respectively) was higher than for sodium and potassium hydroxides (86.71 wt. $\%$ and $91.67 \mathrm{wt} . \%$, respectively). The decrease in the yield for hydroxides is due to saponification reactions of triglycerides and dissolution of methyl ester in glycerol.

The second kind of catalyst used for biodiesel production is acid catalysts, where sulfuric acid is the most commonly used catalyst $[13,14]$, and as shown in the research conducted in [15], this catalyst is characterized by the best fatty acid methyl esters conversion rate in comparison to other acids, such as acetyl chloride, benzenesulfonic acid, sulfuryl chloride, methane sulfonic acid, p-toluenesulfonic acid, thionyl chloride, and dimethyl sulfate. The biodiesel yield was about $80 \%$ for the reaction conducted at $80{ }^{\circ} \mathrm{C}$ for two hours at a weight to volume ratio of 1:5 $(w / v)$ for soybean oil and methanol. The yield of the acid-catalyzed reaction depends, among other things, on process temperature and its time. The higher the temperature and longer the time, the better the conversion rate. In comparison to the alkali-catalyzed process, the reaction with such type of catalyst requires $50 \mathrm{~h}$ to finish and a high temperature (even above $100{ }^{\circ} \mathrm{C}$ ) because the reaction is very slow [16]. This reaction is believed to be four thousand times slower than the alkali-catalyzed reaction [17]. For example, the transesterification of soybean oil with butanol catalyzed by $1 \%$ sulfuric acid at a molar ratio of $1: 30$ was completed in $3 \mathrm{~h}$ when the process temperature was $117^{\circ} \mathrm{C}$, and in $20 \mathrm{~h}$ when it was $77^{\circ} \mathrm{C}$ [18]. The advantage of the acid-catalyzed reaction is the possibility of carrying out the transesterification process for oils containing a significant amount of free fatty acids. Thus, the biodiesel can be produced from low-cost feedstocks (used greases and cooking oil) [19]. The process catalyzed by acids is slower and more corrosive than that catalyzed by alkalis, and therefore it is not often used on an industrial scale [7]. 


\section{Production of Biodiesel by Biological Transesterification Process}

The use of conventional catalysts as acids and bases for biodiesel production leads to the downstream processing connected with by-products' recovery. Transesterification with these catalysts has some disadvantages, such as [20]: low level of free fatty acids (for alkali-catalyzed reactions), requires high temperatures to conduct the process, very difficult process of glycerol purification, transesterification reaction catalyzed by acid needs higher alcohol-to-oil molar ratios, acids cause corrosion of the reactor, soap formation during the base-catalyzed reaction, and purification of methyl esters requires large amounts of water, which influences the operational cost. These disadvantages have led to the investigation of alternative methods of biodiesel production, for example methods that eliminate the adverse effects of chemical catalysts by replacing them with biological ones. Such solutions include catalysis with the participation of enzymes showing substrate specificity in relation to fats. Moreover, replacing chemical with biological catalysts reduces the negative environmental impact of the production technology. This is due to the simplification of the product purification stage and thus energy savings [21].

Lipases are a group of enzymes belonging to the hydrolases. Hydrolases catalyze the decomposition of esters formed by short- and long-chain acids. They show increased activity against esters of glycerol and long-chain fatty acids having more than 10 carbon atoms [22]. Unlike other enzymes, lipases act on water-insoluble substrates. Therefore, the reactions catalyzed by lipases take place at the interfacial border between the lipid phase (substrate) and the water phase in which the enzyme dissolves. In an aqueous medium, lipases catalyze the triglycerides' hydrolysis reaction. For this reason, the water content of the mixture during transesterification is therefore a key parameter and should be kept as low as possible. Otherwise, the thermodynamic equilibrium of the reaction changes from esterification to hydrolysis [23].

Lipases are widely distributed in nature. They are found in seeds and vegetative organs of many plants, in some microorganisms (bacteria and fungi), and in human and animal organisms (liver, pancreas, stomach, and intestine walls). Plant lipases have no industrial application, unlike lipases of microbial and animal origin. Depending on the site of enzyme secretion, we can divide them into extracellular and intracellular. Extracellular lipases require complex purification procedures before being used as a catalyst. In the case of microbial cells producing intracellular lipase, whole cells can be used as catalysts to carry out triglyceride conversion [24].

The decisive factor in the industrial application of lipases is their specificity. Taking this criterion into account, lipases are divided into three groups [25]:

- Lipases that show broad specificity, i.e., they act on all ester bonds in the triglyceride molecule (e.g., lipases from Staphylococcus aureus and Candida rugosa).

- Lipases having specificity for positions 1 and 3 in triglycerides (e.g., lipases produced by fungi of the genera Mucor and Aspergillus or by yeast such as Candida lipolytica and Candida dejormance).

- Lipases having specificity for position 2 in triglycerides (e.g., lipase synthesized by Galactomyces geotrichum).

Purified lipase can be used commercially in the form of powder. Such enzymes can be used directly in nonaqueous solvent or in a dissolved form in an aqueous medium. Lipases are active over a wide range of $\mathrm{pH}$ and temperature. The optimal $\mathrm{pH}$ condition of action for plant lipases is 4.5-5.0, and 7.0-8.0 for lipases of animal origin, while the most effective temperature ranges from 35 to $37^{\circ} \mathrm{C}$. For the microbial lipases, the highest activity falls within the range of $\mathrm{pH}$ from 8 to 9 and at $30-40{ }^{\circ} \mathrm{C}$ [25]. The authors of [26] isolated the LipB68 enzyme, which enables the transesterification process to be carried out with $92 \%$ efficiency within $12 \mathrm{~h}$. This enzyme has a unique optimum temperature of $20^{\circ} \mathrm{C}$.

The use of enzymes in biodiesel production has a lot of advantages, such as [20]: the possibility to work under different environments (aqueous and nonaqueous), the possibility of enzyme production in bulk, ease of adaptation of enzymes, no separation is required when transesterification is conducted in a packed-bed reactor, and the good thermal 
stability of lipases enables to carry out the process at elevated temperatures. Lipases also have their drawbacks. Under the influence of methanol, they are deactivated, so the efficiency of the process may be low. The problem can be prevented by gradual methanol dosing. As a result, the conversion efficiency of oil to biodiesel is around 98\% [27]. The inhibitory effect of methanol on the process can also be minimized by using the addition of tert-butanol as a solvent. The authors of [28] studied enzymatic production of biodiesel in t-butanol solvent with the use Candida antarctica lipase as a catalyst. It has been stated that for a reaction mixture containing $32.5 \%$ t-butanol, $13.5 \%$ methanol, $54 \%$ oil, and $0.017 \mathrm{~g}$ of enzyme (g oil) $)^{-1}$, the yield of biodiesel was $97 \%$ (after $24 \mathrm{~h}$ at $50^{\circ} \mathrm{C}$ ).

A compound that also strongly inhibits the enzymatic transesterification process is glycerin (by-product of the reaction). To avoid this effect, glycerin should be removed from the reaction medium, for example by washing the immobilized enzyme with isopropanol after each transesterification cycle [29]. Another way to remove glycerin is dialysis into the aqueous phase, e.g., using a flat-sheet membrane module [30]. The presence of phospholipids in the oil may also inhibit the process. The authors of [31] studied methanolysis of soybean oil with the use of Candida antarctica lipase. They stated that crude oil did not undergo the transesterification process while degummed oil did. The inhibition was caused by the interaction of the phospholipids with lipase, so before the process the oil should be degummed.

Other disadvantages of the lipase-catalyzed process are the high costs of the enzymes (caused by costs of separation and purification) and their poor stability. These drawbacks can be partially overcome by immobilization of enzymes, i.e., the binding of the enzymes to a solid support that is insoluble in the reaction medium, without affecting their catalytic properties. Immobilization of the enzyme allows for easier separation of the catalyst (e.g., by filtration, centrifugation) from the reaction mixture after the end of the process. Immobilization also prolongs the catalytic activity of the enzyme, which enables its reuse in subsequent reaction cycles [32]. This process stabilizes and strengthens the entire protein structure, which increases the resistance of the enzyme to the adverse effects of $\mathrm{pH}$, temperature, or chemicals. Additionally, immobilized enzymes retain high activity and catalytic functions in organic solvents, which is not possible with the use of a soluble form of this catalyst. Binding the enzymes to the substrate allows the reaction to be carried out in various reactors (batchwise, continuous), because it is possible to constantly supply the substrates and collect the reaction products [33].

The factor determining the division of immobilization methods is the type of interactions between the catalyst and the carrier. There are five main methods: adsorption, covalent binding, entrapment, encapsulation, and cross-linking. The choice of the method depends on several factors, such as the type of carrier, the type of enzyme, the nature of the catalyzed reaction, or the required stability of the immobilized catalyst [20]. For example, the authors of [34] studied, inter alia, the influence of the type of carrier (LifetechTM ECR1061M, LifetechTM ECR8804M, LifetechTM ECR8806M, LifetechTM ECR1090M, and LifetechTM ECR1030M) and the type of lipase (from: Rhizomucor miehie, Thermomyces lanuginosus, Candida antarctica, and the ultra-phospholipase of Lecitase antarctica), and the ultra-phospholipase reactions of Lecitase oil and the phospholipase reactions. Their performances were compared with commercial biocatalysts (TL-IM, RM-IM, Novozyme 435). It was found that some of the tested systems (enzyme-carrier) showed better performance than commercial biocatalysts. This may be related to better diffusion of the substrate into the active center of the enzyme.

Enzyme-catalyzed transesterification has one more advantage: free fatty acids contained in oils do not constitute an obstacle in the process and can be completely converted to methyl esters [8]. Work is also carried out on replacing alcohols with other compounds that are acyl acceptors in order to increase the effectiveness of the transesterification process (elimination of the inhibition effect). The authors of [35] investigated the possibility of transesterification of five different oils during lipase-catalyzed transesterification, with methyl acetate as an acyl acceptor. They stated that under optimal reaction conditions, 
tested fats (plant oils and animal fats) led to high yields of methyl ester on the level from $91 \%$ (for soybean oil) to $98 \%$ (for cotton-seed oil).

The use of lipases can reduce the cost, due to easier separation of product and glycerol, lack of side reactions, and reduced wastewater treatment [36]. The lipase-catalyzed process enables to use low-quality oils containing high free fatty acid content as a substrate. In Table 1, the transesterification methods are compared using different types of catalysts.

Table 1. Comparison of transesterification methods with the use of different types of catalysts $[7,8,11,20,25,26,37]$.

\begin{tabular}{|c|c|c|c|}
\hline Parameter & Alkali-Catalyzed Process & Acid-Catalyzed Process & Enzyme-Catalyzed Process \\
\hline Reaction temperature & $(60-70)^{\circ} \mathrm{C}$ & $(70-120)^{\circ} \mathrm{C}$ & $(20-40){ }^{\circ} \mathrm{C}$ \\
\hline Reaction time & $(1-8) \mathrm{h}$ & $(3-50) \mathrm{h}$ & $(4-72) \mathrm{h}$ \\
\hline Biodiesel yield & $(86-99) \%$ & $97 \%$ & $(86-100) \%$ \\
\hline Alcohol to oil ratio & $(3.3-6): 1$ & $(20-30): 1$ & $(4-6): 1$ \\
\hline Free acids in raw material & Products of saponification & Esters & Esters \\
\hline Water in raw material & Affects negatively & - & $\begin{array}{c}\text { Depends on the type and form } \\
\text { of lipase and the presence } \\
\text { of organic solvent }\end{array}$ \\
\hline Glycerol separation & Hard & Hard & Easy \\
\hline Purification of product & Washing & Washing & Not necessary \\
\hline Cost of catalyst & Low & Low & High \\
\hline Energy consumption & High & High & $\begin{array}{l}\text { Lower than in alkali- and } \\
\text { acid-catalyzed processes }\end{array}$ \\
\hline Corrosion & Low & High & Low \\
\hline
\end{tabular}

The main benefits of using an enzyme catalyst include lowering the reaction temperature, the possibility of using a lower quality raw material (containing free fatty acids), eliminating the dangers of soap formation, increasing the efficiency of the reaction, and no difficulties in the process of glycerin recovery and ester purification. The use of enzymatic catalysts that eliminate the disadvantages of inorganic processes listed in Table 1 requires a lot of research to solve technological problems that limit their profitability [38]. As shown in [39], the product of transesterification using the biocatalytic approach can be much cleaner and less energy-demanding in comparison with chemical catalysts. It has been shown that the biocatalysis could be comparable with the conventional catalysis reaction in the production of biodiesel, taking into account the reaction rate and conversion.

The technology of biodiesel production is constantly being developed, which is caused by the increase of biofuels' demand. This is reflected in the number of published new solutions of biodiesel production. For the last 20 years, these solutions have generally been related to: reactors $(55 \%)$, raw materials $(21 \%)$, catalysts $(9 \%)$, pre-treatment $(13 \%)$, and testing methods (2\%) [40]. In the field of biodiesel production through lipase catalysis, the changes are mainly aimed at: raw materials' quality, enzymes, process parameters, acyl acceptors, solvents, and reactor systems.

The raw materials' selection is very important because their cost represents nearly $80 \%$ of the biodiesel production cost. In that area, research is underway to change food feedstocks into non-food and waste ones [41,42]. As feedstocks, different types of nonedible oil raw materials have been investigated, such as: Jatropha seeds, Calophyllum inophyllum, tobacco, rubber, mahua, Cotton seeds, Karanja seeds, Castor seeds, Cynara cardunculus L. seeds oil factory wastes, industrial by-products rich in fatty acids (palm oil sludge, waste cooking oils), animal fats, spent coffee grounds, and municipal sludge [43-46]. Moreover, research is conducted on the microorganisms (e.g., microalgae) as a biomass rich in lipids [47-49]. Algae are promising sources in biodiesel production because of the potential high oil content and fast generation of biomass. However, the big problem 
in algae cultivation is proper temperature for their optimal growing (about $15-30{ }^{\circ} \mathrm{C}$ ), which may be a significant obstacle to the common use of this type of raw material for fuel production, especially in the countries with a cold climate. In these kinds of countries, the algae should be cultivated in special kinds of bioreactors using energy to maintain the required temperature and access to light.

Due to the high costs of enzymes, which limit the widespread use of biocatalytic transesterification technology, the work carried out concerns the possibility of obtaining cheaper and more effective biocatalysts. The research is carried out in the fields of:

- Selection of new enzyme sources (new microorganisms such as bacteria, fungi, yeast). Researchers have conducted tests on, for example: Pseudomonas, Candida rugose, Burkholderia, Thermomyces lanuginose, Candida Antarctica, and Aspergillus niger [43,50]. Research is also conducted on the direction of the evolution of microorganisms and their rational design in order to increase the tolerance of lipases produced by them to temperatures or the type of solvent [51].

- Using enzymes used so far in other areas, e.g., phospholipases commonly used, inter alia, in the food industry, in fine chemistry or in the production of aromas and fragrances [34,52], and improvement of enzyme production and quality (increase in catalytic efficiency, substrate specificity, thermostability, etc.) by DNA recombination of microorganisms [37,51].

- Improvement of enzyme efficiency (combining several types of lipase [53]). Phospholipids are inhibitors of transesterification because they interfere with lipase. Studies curried out in [54] indicated that it is possible to obtain biodiesel from crude oil by the degumming-transesterification process, in which the phospholipases are used with a soluble lipase.

- Durability of enzyme immobilization on different materials. The kind of material used depends on the immobilization method. For example, the most commonly used materials for immobilizing lipase by adsorption are silica gel, activated carbon, resins, cellulose, etc. In recent years, there has been a growing interest in the use of nanomaterials to immobilize lipases. Magnetic nanoparticles are of particular interest due to their interesting properties, such us: large surface area, high force of adsorption, low toxicity, and easy separation under the magnetic field [55]. In addition, the surface of magnetic nanoparticles can be modified by depositing functional groups thereon (e.g., amino-silane, hydroxyl group) in order to increase stability, enzymatic efficiency, or the possibility of reusing enzymes [56]. Other nanoparticles are also considered for lipase immobilization by adsorption, e.g., silica nanoparticles, metalorganic framework nanoparticles, carbon nanotubes, organic polymers, nanohybrid materials, or modified fibrous materials [43,57-59].

Many of the tested lipases have high catalytic abilities, which can be additionally intensified by their various methods of deposition on carriers. However, the enzymatic transesterification process still requires further studies. Such studies include optimization of conditions for the reaction (choice of amount of alcohol and oil, lipase concentration, water content, stirrer speed, time, and temperature) through appropriate reaction modeling and design reactors [43]. In order to improve homogeneity, the rate of diffusion of the reaction mixture, and the stability of the enzyme, as well as to avoid problems connected with the formation of two phases and mass transfer, the two-step process and co-solvent system (with acetonitrile, tert-butanol, tert-pentanol, 1,4-dioxane, n-hexane, n-heptane, supercritical carbon dioxide, tetrahydrofuran, ionic liquids) are also tested $[53,60,61]$. In addition to the work on the selection of enzyme systems or the preparation of new biocatalysts, other research is also carried out on the possibility of increasing the efficiency of enzymatic biodiesel production. The directions of research on the development of enzymatic transesterification are shown in Figure 1. These works concern, among others:

- Selection of a co-solvent system in order to improve mass transfer or minimize the inhibitory effect of methanol/glycerol on enzymes. 
- Development of a two-step transesterification method to increase product quality and process efficiency.

- Obtaining by-products of the highest market value in order to minimize the costs of biodiesel production.

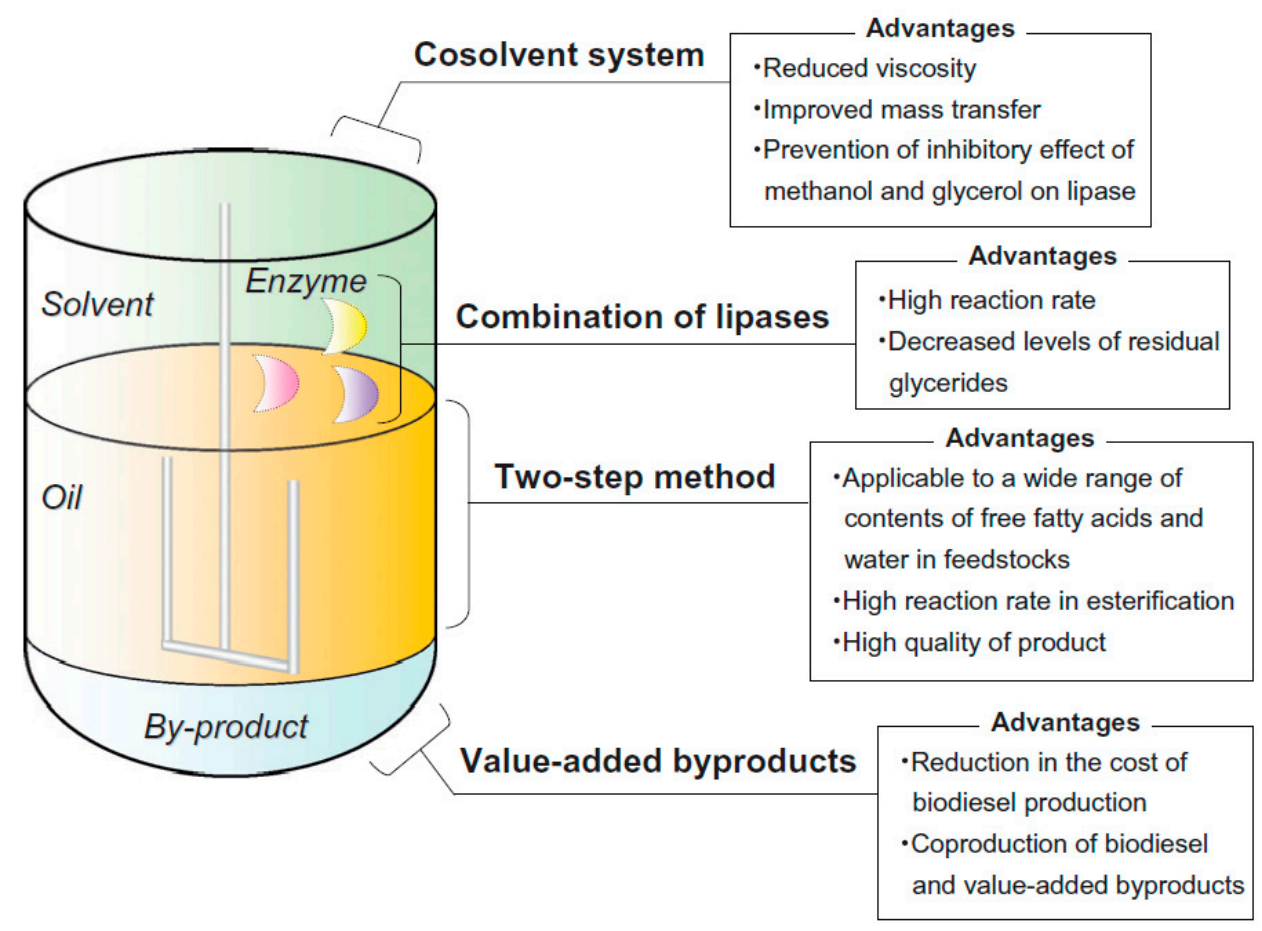

Figure 1. Schematic of approaches to increasing enzymatic biodiesel production [53].

Enzymatic biodiesel production can be realized in either batch or continuous systems and in different kinds of reactors, e.g., in a tubular reactor with static mixers, simulated moving bed, packed-bed tubular, expanded bed reactor, basket-type stirred tank reactor, as well as membrane, recirculation, and expanding bed reactors [20]. The packed-bed reactor, stirred tank reactor, and fluidized bed reactor are the most widely used reactors in enzymatic biodiesel production, and also in continuous systems. Examples of bioreactor types used in the enzyme-catalyzed process are presented in Figure 2.
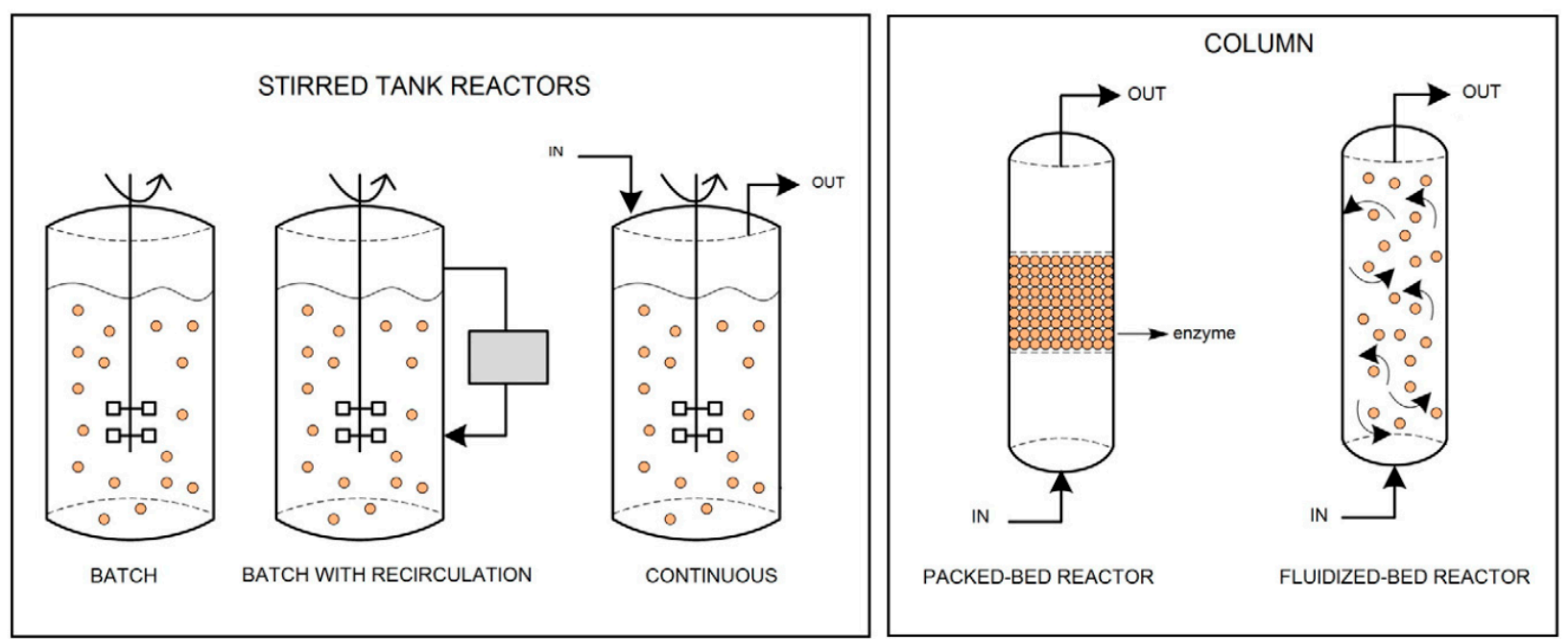

Figure 2. Schematic representation of the main types of bioreactors: left—stirred tank reactors, right—column reactors [62]. 
As shown in Figure 2, the reactors are divided into two groups-mechanically stirred and columnar, capable of operating in batch or continuous mode. In the column reactors, the enzyme is immobilized on the bed, which can be packed and remain stationary (the packed-bed reactor) or suspended (the fluidized bed column reactor), and the substrate solution is pumped through it. In mechanically stirred reactors, the catalyst can be present in or separated from the reaction mixture, e.g., placed in a basket through which the mixture flows.

The choice of the kind of reactor depends on the form of the immobilized enzyme, mass transfer, reaction kinetics, nature of the substrate, operational requirements of the reaction, catalytic surface per unit volume of reactor, construction of the bioreactor, replacement of the catalyst and regeneration, operational cost of the bioreactor, and mode of operation [62]. Batch reactors are the most commonly used bioreactors in the enzymecatalyzed transesterification process. Such a process takes quite a long time so tanks with high volume are required. The activity of enzymes gradually decreases, and the reaction time should be increased to maintain a proper degree of conversion. When the catalyst loses its activity, it must be replaced. Additionally, in batch reactors, a high shear stress caused by the stirrer leads to a disturbance in the work of the catalyst [63]. These disadvantages can be overcome with the use of a reactor with a porous basket. This solution also enables an easy way to separate the catalyst after the reaction. Research has been carried out on the selection of mixing methods, the type of agitators, and their rotational speed in order to optimize the reaction conditions, including mass transfer. The continuous bioreactor has some advantages in comparison with batch reactors, such as better control of process parameters, mass transfer, mixing of reagents, energy efficiency, and product separation (fewer unit operations), and better efficiency of the enzyme used (lower amounts of enzyme per volume in the reactor) [62]. Moreover, using the solutions in the bioreactor which enable stepwise addition of alcohols and continuous removal of glycerol, the conversion yield of transesterification can be improved [64,65].

In the reactors, different solutions are tested which ensure intensification of the transesterification process, e.g., use of supercritical fluids, microwave irradiation, and ultrasound methods. The transesterification under supercritical conditions allows to conduct a reaction without a catalyst (alcohol is both a reactant and an acid catalyst) and affects the improvement of the phase solubility and mass transfer. The reaction needs high alcohol to oil molar ratios and high temperature and pressure conditions, which is the main barrier to overcome $[66,67]$. For transesterification with microwave irradiation, the heat is provided by microwaves instead of the conventional method. The energy is delivered directly to the reactant, which results in more effective heat transfer, reduced energy consumption (compared with conventional heating methods), and an increase in catalyst activity. This method can reduce the time of the reaction, even to approximately 3-15 minutes [68,69], which saves up to more than $44 \%$ of energy [70]. A similar effect as with the use of microwaves is achieved by supporting the transesterification process with ultrasound. Using this method can increase the yield of biodiesel by up to about $30 \%$ compared to conventional stirring, which is caused by the cavitation effect [71]. During cavitation, the asymmetric collapse of the bubbles occurs, which generates micro-turbulence and thus results in mass transfer increases. This eliminates the need of using mechanical stirring. Commercial use of ultrasound techniques has not yet found application, among others due to the lower biodiesel yield in bioreactors with a volume higher than 6 L [72].

\section{Environmental Impact}

The environmental impact of the biodiesel production process largely depends on two factors: the type of raw material and the production technology used. In the case of a raw material, the origin of the raw material has an impact on the lifecycle emission performance. The use of advanced raw materials for the production of biofuels having the status of waste or residue results in a higher reduction of greenhouse gas emissions (compared to biofuels produced from food raw materials). If, on the other hand, the raw 
material is cultivated on purpose, then its acquisition carries a burden on the environment related to, inter alia, the production and use of fertilizers and plant protection products or the combustion of diesel oil during the operation of agricultural machinery. Table 2 shows the impact of the origin of the raw material on the result of GHG emissions in the biodiesel lifecycle [73]. Regardless of the raw material used for the production of biodiesel, it is characterized by a much lower greenhouse gas emission compared to conventional diesel oil (Table 2).

Table 2. GHG emission value and emission reduction in relation to fossil fuel analogue throughout the lifecycle of biodiesel, taking into account the type of raw material [73].

\begin{tabular}{|c|c|c|}
\hline Biodiesel Production Pathway & Default GHG Emission ( $\left.\mathrm{gCO}_{2 \mathrm{eq}} / \mathrm{MJ}\right)$ & Default GHG Saving (\%) \\
\hline rape seed biodiesel & 52 & 38 \\
\hline sunflower biodiesel & 42 & 51 \\
\hline soybean biodiesel & 58 & 31 \\
\hline palm oil biodiesel (process not specified) & 68 & 19 \\
\hline palm oil biodiesel (process with methane capture at oil mill) & 37 & 56 \\
\hline waste vegetable or animal oil biodiesel & 14 & 83 \\
\hline
\end{tabular}

Another aspect influencing the emission result in the biodiesel lifecycle is the technological process. This issue was raised in the literature on the subject, inter alia, by the authors of [74]. The publication presents the results of a comparative environmental lifecycle assessment of two types of biodiesel production processes: enzyme-catalyzed biodiesel production and the alkali-catalyzed biodiesel production technology. In all environmental impact categories, the results were much more favorable for enzyme-catalyzed biodiesel production (Figure 3). Such a result is mainly due to the higher efficiency as well as a shorter course of the enzymatic reaction, a lower reaction temperature, and the lack of alkali compounds, the production of which carries a significant burden on the environment. The only exception is in the respiratory organic category, because of the higher quantity of methanol present in the emission of air for enzyme-catalyzed biodiesel production. The added value of the enzyme-catalyzed biodiesel is also that the reusability of the enzyme will decrease the need for new catalysts, and it is much cleaner from the emission perspective. This LCA study provides additional supportive information that the enzyme-catalyzed biodiesel production contributes less impacts to the environment due to the fact that chemical catalysts and neutralizing acid are not required in the process [74].

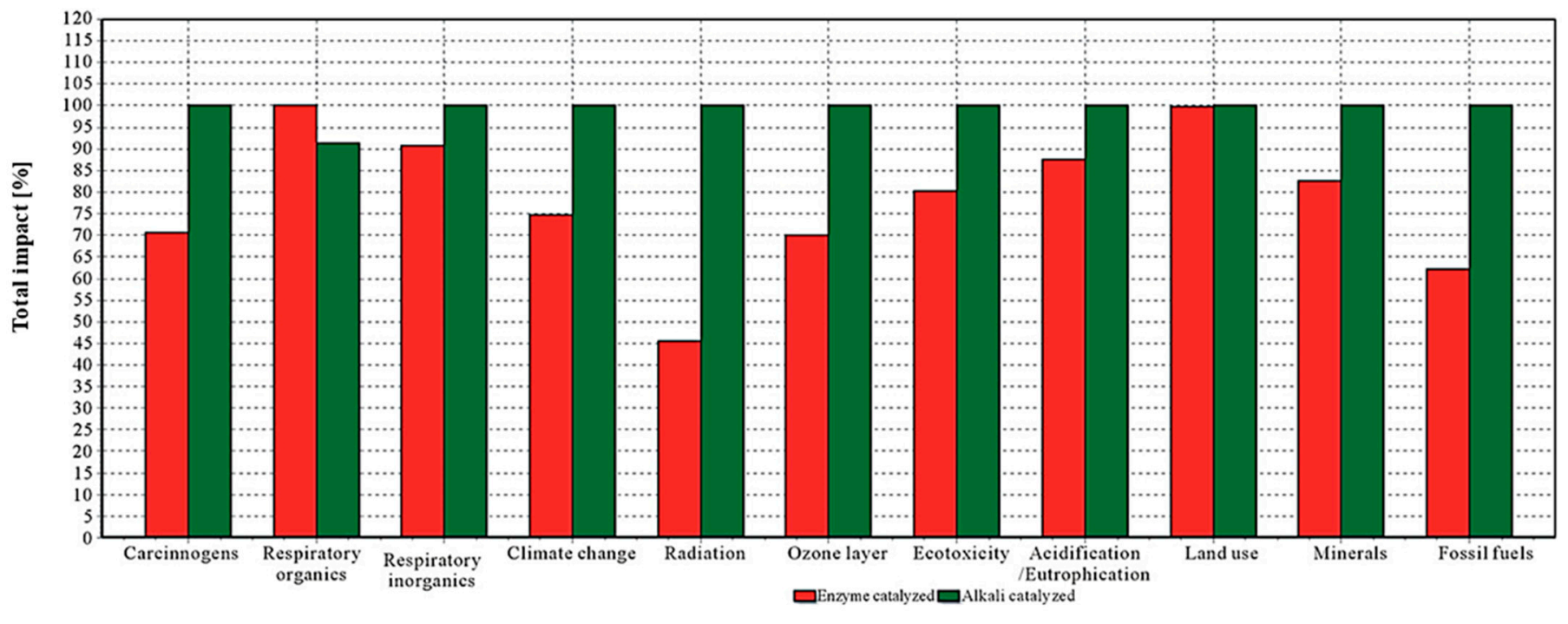

Impact categories

Figure 3. Results of the comparative lifecycle analysis of enzyme-catalyzed biodiesel production and the alkali-catalyzed biodiesel production technology [74]. 
The authors of [75] also point to a much lower impact on the environment of the enzyme-catalyzed biodiesel. The authors of the article conducted a comparative environmental impact analysis of the soybean biodiesel production by two different technologies. The production routes evaluated were the alkali-catalyzed (catalyst: sodium hydroxide) methylic transesterification and the enzyme-catalyzed (catalyst: lipase) ethylic transesterification. The results of the lifecycle regarding material consumption and the evaluation of impact categories such as the greenhouse effect potential (GEP), the potential of ozone layer depletion (OLD), the potential of ozone photochemical formation (OPF), nonrenewable energy usage (NEU), liquid effluents' generation (LEG), solid waste generation (SWG), and the acidification potential (ACP), indicated the environmental benefits of the ethanol usage instead of methanol and of the enzymatic technology over the traditional alkaline technology [75]. These benefits are visible in all categories, with the exception of the potential of ozone photochemical formation of the methylic route (Figure 4). This result is mainly because of the methanol production, where hydrocarbons are released during natural gas processing. On the other hand, the most favorable results were obtained for the ethylic route in the GEP category. The ethylic route presents a negative value connected to the carbon sequestration during two agricultural stages: soybean production and sugarcane production. The methylic route presents a significant positive contribution to the carbon dioxide release from the methanol production processes [75].

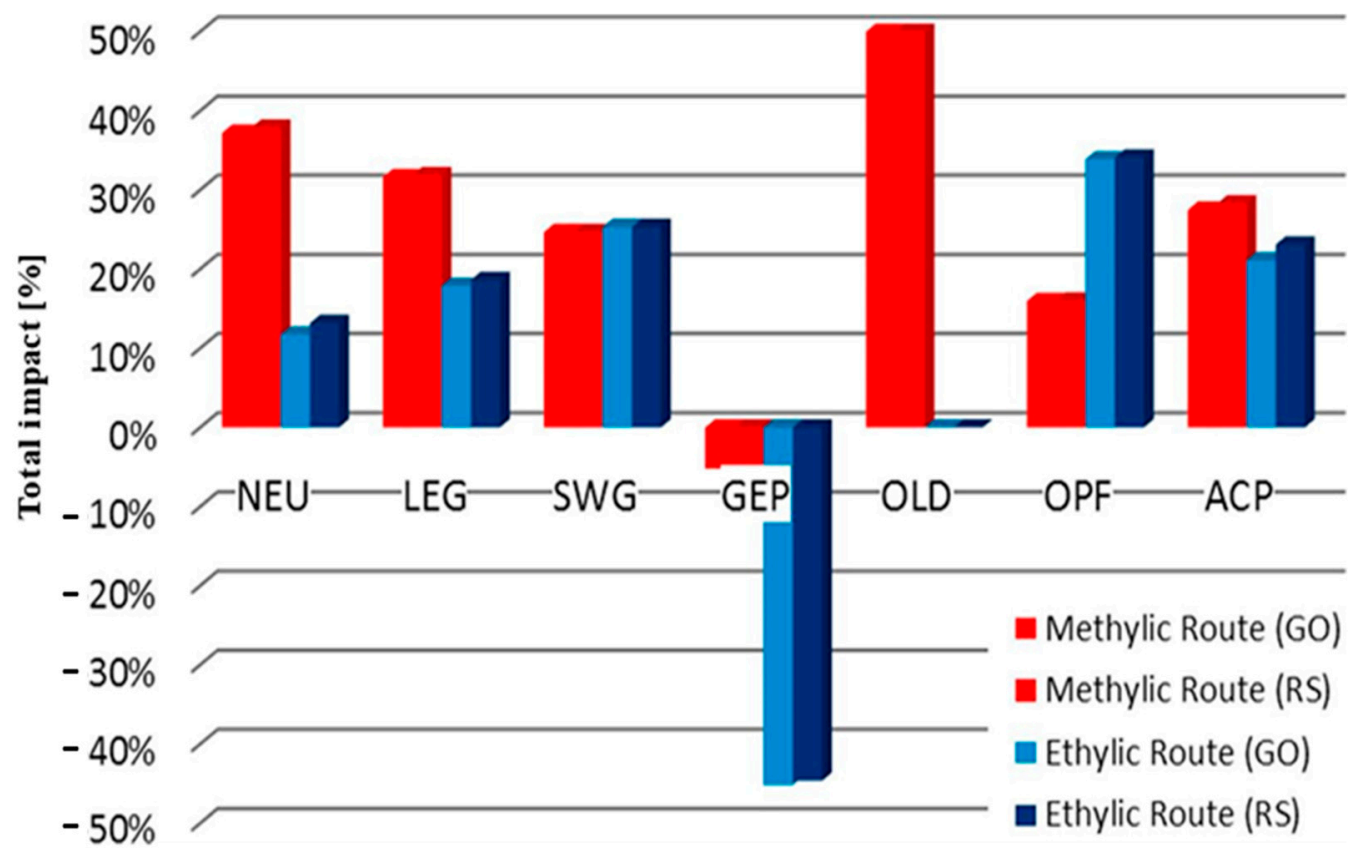

Impact categories

Figure 4. Comparative environmental impact analysis of the soybean biodiesel production by two different technologies: the alkali-catalyzed methylic transesterification and the enzyme-catalyzed ethylic transesterification for two different localizations, where NEU is non-renewable energy usage, LEG — liquid effluents' generation, SWG—solid waste generation, GEP — the greenhouse effect potential, OLD—-the potential of ozone layer depletion, OPF-the potential of ozone photochemical formation, and $\mathrm{ACP}$ - the acidification potential [75].

The authors of [76] emphasize the impact of the type of raw material and its origin on the total result of emissions in the whole lifecycle. The alkali-catalyzed biodiesel production process, where the virgin soybean oil was used as a substrate (Case 1), with enzyme-catalyzed biodiesel produced from virgin soybean oil (Case 2), and with waste cooking oil (UCO) (Case 3), was subjected to LCA analysis. The LCA included the following impact categories: Global Warming Potential (GWP), Ozone Layer Depletion Potential 
(ODP), Photochemical Ozone Creation Potential (POCP), Human Toxicity Potential (HTP), Abiotic Depletion Potential (ADP), Fresh Water Aquatic Ecotoxicity Potential (FAETP), Marine Aquatic Ecotoxicity Potential (MAETP), Terrestrial Ecotoxicity Potential (TETP), Acidification Potential (AP), and Eutrophication Potential (EP) [76]. The obtained results show a clear environmental advantage of the enzyme-catalyzed biodiesel produced from UCO in all the above-mentioned impact categories (Figure 5). This result is mainly influenced by the waste origin of the UCO, and thus the zero GHG emission attributed to the remaining raw material stage. The category where the environmental advantage of biodiesel made from UCO over biodiesel made from soybean oil is particularly prominent is GWP100. The agricultural stage related to the cultivation of soybean has the main influence on this result. This result is related to the necessity of intending land for soybean cultivation and the use of mineral fertilizers and plant protection products, for which production and application of the plantation is energy-intensive and results in significant emissions of particulate matter and gases into the air. From the analysis results, the fuel combustion, mainly diesel fuel, also has a significant influence during field work.

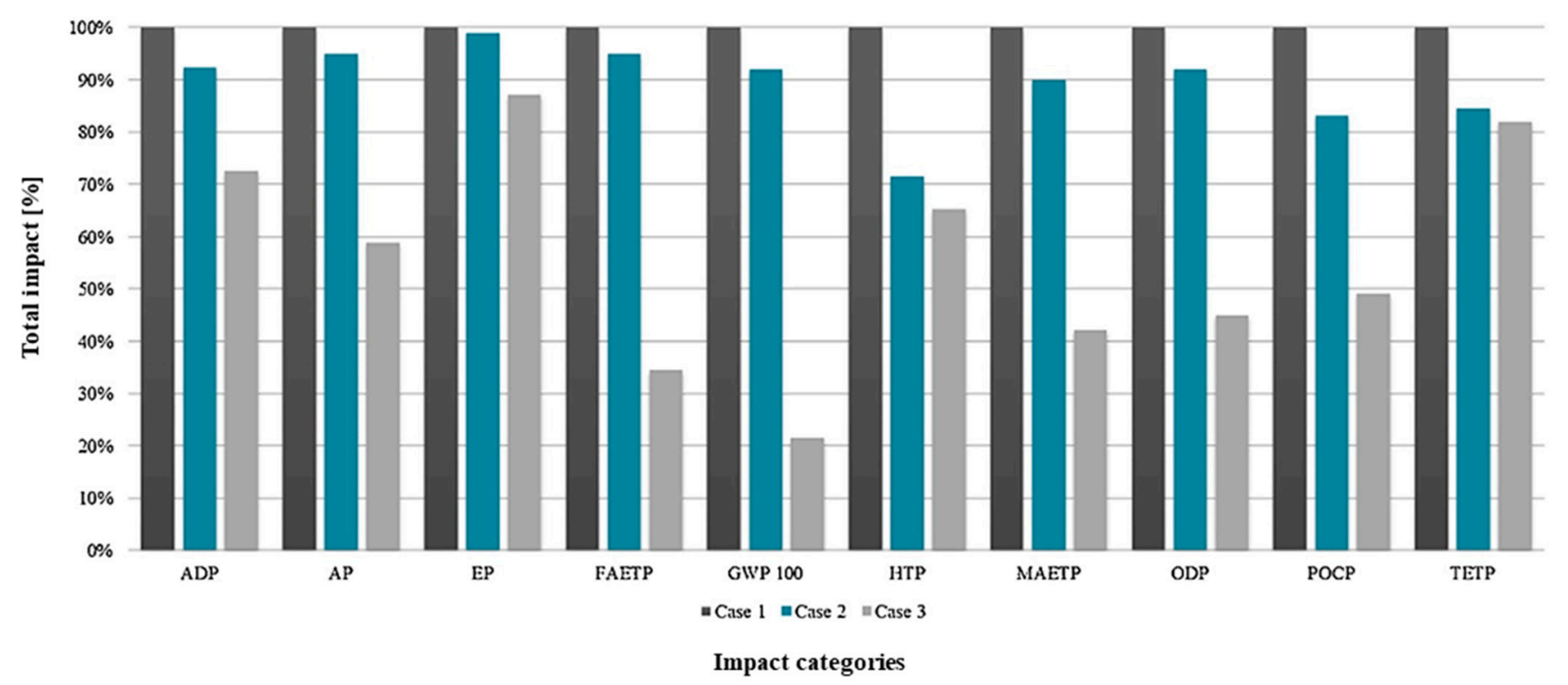

Figure 5. The comparative LCA results for the three cases: (Case 1) alkali-catalyzed with virgin soybean oil, (Case 2) enzyme-catalyzed with virgin soybean oil, and (Case 3) enzyme-catalyzed with WCO. The main impact categories were: Abiotic Depletion Potential (ADP), Global Warming Potential (GWP), Ozone Layer Depletion Potential (ODP), Human Toxicity Potential (HTP), Fresh Water Aquatic Ecotoxicity Potential (FAETP), Marine Aquatic Ecotoxicity Potential (MAETP), Terrestrial Ecotoxicity Potential (TETP), Photochemical Ozone Creation Potential (POCP), Acidification Potential (AP), and Eutrophication Potential (EP) [76].

The results of the environmental lifecycle assessment of various biodiesel production technologies presented above show that biodiesel produced with the enzymatic method is characterized by much more favorable environmental parameters [74-76]. The main advantage of the enzymatic method over the alkaline or acidic method is, inter alia, the lower temperature of the process, which in turn translates into lower GHG emissions associated with the need to provide less heat to the process. Moreover, the process of purifying the final product is much simpler due to the easy separation of the catalyst and the separation of glycerin, which directly reduces the material and energy expenditure. The kind of raw material and its origin also has a direct impact on reducing GHG emissions over the lifecycle. If the raw material is of waste origin, then it has zero greenhouse gas emissions at the stage of its acquisition. If, on the other hand, it is harvested on purpose (such as rape or soybean), then the final emission is influenced by the cultivation process (especially the highly energy-consuming and emission-intensive process of nitrogen fertilizer production). 


\section{Conclusions}

The transport sector is one of the largest greenhouse gas emitters in the world. For this reason, there has been a need to find environmentally friendly solutions, including in technologies of the production of alternative fuels', especially from renewable plant resources. One such fuel is biodiesel, which is produced by the method of transesterification of fats with different alcohols and in the presence of different catalysts. The traditional methods of biofuel production with the use of acid and base catalysts were under strong investigation and considered as close to their limits, and are currently under marginal development. Moreover, transesterification with these catalysts has some disadvantages, which can be overcome by replacing them with biological ones. The use of an enzymatic catalyst enables to carry out the process at lower temperatures and with the use of raw materials of lower quality (containing free fatty acids). Other significant advantages are: increased reaction efficiency, reduced product and glycerol separation costs, and the possibility to work under different environments (aqueous and nonaqueous). The lower temperature of the enzymatic process and lower cost of separation of the catalyst and the final products translate into lower GHG emissions compared to a chemically catalyzed process. This is associated with the need to provide less heat to the process.

Unfortunately, despite numerous advantages, the wide application of the enzymatic biodiesel production method is still limited due to disadvantages such as sensitivity of enzymes to inhibitors (methanol, glycerin) or high costs of enzyme production. Therefore, the use of the biological method of biodiesel production on a larger scale requires further work to minimize the disadvantages associated with the process. For this reason, in order to improve the qualitative and quantitative performance and economic efficiency of the process, it is necessary to continue research, e.g., in the area of new enzymes and their sources, selection of solvents, or optimization of process conditions.

Biocatalytic transesterification is a promising technology for biodiesel production. After reducing the process barriers, this technology will be able to compete with the chemical catalysis methods and will be universally applicable.

Author Contributions: Conceptualization, K.B., A.M., I.S.-B. and M.O.; methodology, A.M., I.S.-B. and M.O.; writing—original draft preparation, A.M., I.S.-B. and M.O.; writing-review and editing, K.B. All authors have read and agreed to the published version of the manuscript.

Funding: This research received no external funding.

Institutional Review Board Statement: Not applicable.

Informed Consent Statement: Not applicable.

Conflicts of Interest: The authors declare no conflict of interest.

\section{References}

1. Hoang, A.T.; Noor, M.M.; Pham, X.D. Comparative Analysis on Performance and Emission Characteristic of Diesel Engine Fueled with Heated Coconut Oil and Diesel Fuel. Int. J. Automot. Mech. Eng. 2018, 15, 5110-5125.

2. Hamelinck, C.; Spottle, M.; Mark, L.; Staats, M. Possibilities of Transport Decarbonising by 2030; ECOFYS: Utrecht, The Netherlands, 2019.

3. European Environment Agency. Trends and Projections in Europe 2018-Tracking Progress towards Europe's Climate and Energy Targets; European Environment Agency: Copenhagen, Denmark, 2018.

4. Technology Roadmap. Biofuels for Transport; International Energy Agency: Paris, France, 2011.

5. Daniell, J.; Köpke, M.; Simpson, S.D. Commercial Biomass Syngas Fermentation. Energies 2012, 12, 5372-5417. [CrossRef]

6. Bacenetti, J.; Restuccia, A.; Schillaci, G.; Failla, S. Biodiesel production from unconventional oilseed crops (Linum usitatissimum L. and Camelina sativa L.) in Mediterranean conditions: Environmental sustainability assessment. Renew. Energy 2017, 112, 444-456. [CrossRef]

7. Ma, F.; Hanna, M.A. Biodiesel production: A review. Bioresour. Technol. 1999, 70, 1-15. [CrossRef]

8. Fukuda, H.; Kondo, A.; Noda, H. Review. Biodiesel Fuel Production by Transesterification of Oils. J. Biosci. Bioeng. 2001, 92, 405-416. [PubMed]

9. Wright, H.J.; Segur, J.B.; Clark, H.V.; Coburn, S.K.; Langdon, E.E.; Dupuis, R.N. A Report on Ester Interchange. Oil Soap 1944, 21, 145-148. [CrossRef] 
10. Marchetti, J.M.; Miguel, V.U.; Errazu, A.F. Possible methods for biodiesel production. Renew. Sustain. Energy Rev. 2007, 11, 1300-1311. [CrossRef]

11. Nasreen, S.; Nafees, M.; Qureshi, L.A.; Asad, M.S.; Sadiq, A.; Ali, S.D. Review of Catalytic Transesterification Methods for Biodiesel Production. In Biofuels—State of Development; Biernat, K., Ed.; IntechOpen: London, UK, 2018; pp. 93-119.

12. Vicente, G.; Martinez, M.; Aracil, J. Integrated biodiesel production: A comparison of different homogeneous catalysts systems. Bioresour. Technol. 2004, 92, 297-305. [CrossRef]

13. Ferdous, K.; Uddin, M.R.; Mondal, S.K.; Khan, M.R. Preparation of Biodiesel Using Sulfuric Acid as a Catalyst. In Proceedings of the International Conference on Engineering Research, Innovation and Education 2013, CERIE 2013, SUST, Sylhet, Bangladesh, 11-13 January 2013.

14. Marchetti, J.M.; Pedernera, M.N.; Schbib, N.S. Production of biodiesel from acid oil using sulfuric acid as catalyst: Kinetics study. Int. J. Low-Carbon Technol. 2010, 6, 38-43. [CrossRef]

15. Linh, T.H.; Ryu, Y.J.; Seong, D.H.; Lim, S.M. An effective acid catalyst for biodiesel production from impure raw feedstocks. Biotechnol. Bioprocess. Eng. 2013, 18, 242-247.

16. Pathak, S. Acid catalyzed transesterification. J. Chem. Pharm. Res. 2015, 7, 1780-1786.

17. Vyas, A.P.; Verma, J.L.; Subrahmanyam, N. A review on FAME production processes. Fuel 2010, 89, 1-9. [CrossRef]

18. Freedman, B.; Butterfield, R.O.; Pryde, E.H. Transesterification Kinetics of Soybean Oil. J. Am. Oil Chem. Soc. 1986, 63, 1375-1380. [CrossRef]

19. Lotero, E.; Liu, Y.; Lopez, D.E.; Suwannakarn, K.; Bruce, D.A.; Goodwin, J.G. Synthesis of Biodiesel via Acid Catalysis. Ind. Eng. Chem. Res. 2005, 44, 5353-5363. [CrossRef]

20. Baadhe, R.R.; Potumarthi, R.; Gupta, V.K. Chapter 8-Lipase-Catalyzed Biodiesel Production: Technical Challenges. In Bioenergy Research: Advances and Applications; Elsevier: Amsterdam, The Netherlands, 2014; pp. 119-129.

21. Harding, K.G.; Dennis, J.S.; von Blottnitz, H.; Harrison, S.T.L. A life-cycle comparison between inorganic and biological catalysis for the production of biodiesel. J. Clean. Prod. 2008, 16, 1368-1378. [CrossRef]

22. Ribeiro, B.D.; de Castro, A.M.; Coelho, M.A.Z.; Freire, D.M.G. Production and Use of Lipases in Bioenergy: A Review from the Feedstocks to Biodiesel Production. Enzym. Res. 2011, 2011, 615803. [CrossRef] [PubMed]

23. Bancerz, R. Przemysłowe zastosowania lipaz. Postępy Biochem. 2017, 63, 335-341. (In Polish)

24. Xiao, M.; Mathew, S.; Obbard, J.P. Biodiesel fuel production via transesterification of oils using lipase biocatalyst. GCB Bioenergy 2009, 1, 115-125. [CrossRef]

25. Adamczak, M.; Bednarski, W. Lipazy-Narzędzie w biotechnologii tłuszczów i olejów. Biotechnologia 1994, 27, 140-153. (In Polish)

26. Luo, Y.; Zheng, Y.; Jiang, Z.; Ma, Y.; Wei, D. A novel psychrophilic lipase from Pseudomonas fluorescens with unique property in chiral resolution and biodiesel production via transesterification. Appl. Microbiol. Biotechnol. 2006, 73, 349-355. [CrossRef] [PubMed]

27. Shimada, Y.; Watanabe, Y.; Sugihara, A.; Tominaga, Y. Enzymatic alcoholysis for biodiesel fuel production and application of the reaction to oil processing. J. Mol. Catal. B Enzym. 2002, 17, 133-142. [CrossRef]

28. Royon, D.; Daz, M.; Ellenrieder, G.; Locatelli, S. Enzymatic production of biodiesel from cotton seed oil using t-butanol as a solvent. Bioresour. Technol. 2007, 98, 648-653. [CrossRef]

29. Xu, Y.; Du, W.; Zeng, J.; Liu, D. Conversion of Soybean Oil to Biodiesel Fuel Using Lipozyme TL IM in a Solvent-free Medium. Biocatal. Biotransform. 2004, 22, 45-48.

30. Bélafi-Bakó, K.; Kovács, F.; Gubicza, L.; Hancsók, J. Enzymatic Biodiesel Production from Sunflower Oil by Candida antarctica Lipase in a Solvent-free System. Biocatal. Biotransform. 2002, 20, 437-439. [CrossRef]

31. Watanabe, Y.; Shimada, Y.; Sugihara, A.; Tominaga, Y. Conversion of degummed soybean oil to biodiesel fuel with immobilized Candida antarctica lipase. J. Mol. Catal. B Enzym. 2002, 17, 151-155. [CrossRef]

32. Jia, F.; Narasimhan, B.; Mallapragada, S. Materials-based strategies for multi-enzyme immobilization and co-localization: A review. Biotechnol. Bioeng. 2014, 111, 209-222. [CrossRef]

33. Bezerra, C.S.; de Farias Lemos, C.M.G.; de Sousa, M.; Gonçalves, L.R.B. Enzyme immobilization onto renewable polymeric matrixes: Past, present, and future trends. J. Appl. Polym. Sci. 2015, 132, 42125. [CrossRef]

34. Tacias-Pascacio, V.G.; Virgen-Ortíz, J.J.; Jiménez-Pérez, M.; Yates, M.; Torrestiana-Sanchez, B.; Rosales-Quintero, A.; FernandezLafuente, R. Evaluation of different lipase biocatalysts in the production of biodiesel from used cooking oil: Critical role of the immobilization support. Fuel 2017, 200, 1-10. [CrossRef]

35. Huang, Y.; Yan, Y. Lipase-Catalyzed Biodiesel Production with Methyl Acetateas Acyl Acceptor. Z. Nat. C 2008, 63, 297-302.

36. Bisen, P.S.; Sanodiya, B.S.; Thakur, G.S.; Baghel, R.K.; Prasad, G.B.K.S. Biodiesel production with special emphasis on lipasecatalyzed transesterification. Biotechnol. Lett. 2010, 32, 1019-1030. [CrossRef]

37. Fjerbaek, L.; Christensen, K.V.; Norddahl, B. A review of the current state of biodiesel production using enzymatic transesterification. Biotechnol. Bioeng. 2009, 102, 1298-1315. [CrossRef]

38. Lv, L.; Dai, L.; Du, W.; Liu, D. Progress in Enzymatic Biodiesel Production andCommercialization. Processes 2021, 9, 355. [CrossRef]

39. Tacias-Pascacio, V.G.; Torrestiana-Sanchez, B.; Dal Magro, L.; Virgen-Ortíz, J.J.; Suarez-Ruíz, F.J.; Rodrigues, R.C.; FernandezLafuente, R. Comparison of acid, basic and enzymatic catalysis on the production of biodiesel after RSM optimization. Renew. Energy 2019, 135, 1-9. [CrossRef] 
40. Mahlia, T.M.I.; Syazmi, Z.A.H.S.; Mofijur, M.; Pg Abas, A.E.; Bilad, M.R.; Ong, H.C.; Silitonga, A.S. Patent landscape review on biodiesel production: Technology updates. Renew. Sustain. Energy Rev. 2020, 118, 109526. [CrossRef]

41. Gnanaprakasam, A.; Sivakumar, V.M.; Surendhar, A.; Thirumarimurugan, M.; Kannadasan, T. Recent Strategy of Biodiesel Production from Waste Cooking Oiland Process Influencing Parameters: A Review. J. Energy 2013, 2013, 926392. [CrossRef]

42. Sarno, M.; Iuliano, M. Biodiesel production from waste cooking oil. Green Process. Synth. 2019, 8, 53. [CrossRef]

43. Amini, Z.; Ilham, Z.; Ong, H.C.; Mazaheri, H.; Chen, W.H. State of the art and prospective of lipase-catalyzed transesterification reaction for biodiesel production. Energy Convers. Manag. 2017, 141, 339-353. [CrossRef]

44. Sendzikiene, E.; Santaraite, M.; Makareviciene, V. Lipase-Catalysed In Situ Transesterification of Waste Rapeseed Oil to Produce Diesel-Biodiesel Blends. Processes 2020, 8, 1118. [CrossRef]

45. Patel, R.L.; Sankhavara, C.D. Biodiesel production from Karanja oil and its use in diesel engine a review. Renew. Sustain. Energy Rev. 2017, 71, 464-474. [CrossRef]

46. Liu, Y.; Tu, Q.; Knothe, G.; Lu, M. Direct transesterification of spent coffee grounds for biodiesel production. Fuel 2017, 199, 157-161. [CrossRef]

47. Vassilev, S.V.; Vassileva, C.G. Composition, properties and challenges of algae biomass for biofuel application: An overview. Fuel 2016, 181, 1-33. [CrossRef]

48. Duraiarasan, S.; Razack, S.A.; Manickam, A.; Munusamy, A.; Syed, M.B.; Ali, M.Y.; Ahmed, G.M.; Mohiuddin, M.S. Direct conversion of lipids from marine microalga C. salina to biodiesel with immobilised enzymes using magnetic nanoparticle. $J$. Environ. Chem. Eng. 2016, 4, 1393-1398. [CrossRef]

49. Martínez, N.; Callejas, N.; Morais, E.G.; Costa, J.A.V.; Jachmanián, I.; Vieitez, I. Obtaining biodiesel from microalgae oil using ultrasound-assisted in-situ alkaline transesterification. Fuel 2017, 202, 512-519. [CrossRef]

50. Riosa, N.S.; Pinheiroa, B.B.; Pinheiroa, M.P.; Bezerraa, R.M.; Santosb, J.C.S.; Gonçalvesa, L.R.B. Biotechnological potential of lipases from Pseudomonas: Sources, properties and applications. Process. Biochem. 2018, 75, 99-120. [CrossRef]

51. Hama, S.; Noda, H.; Kondo, A. How lipase technology contributes to evolution of biodiesel production using multiple feedstocks. Curr. Opin. Biotechnol. 2018, 50, 57-64. [CrossRef]

52. Virgen-Ortíz, J.J.; dos Santos, J.C.S.; Ortiz, C.; Berenguer-Murcia, A.; Barbosa, O.; Rodrigues, R.C.; Fernandez-Lafuente, R. Lecitase ultra: A phospholipase with great potential in biocatalysis. Mol. Catal. 2019, 473, 110405. [CrossRef]

53. Hama, S.; Kondo, A. Enzymatic biodiesel production: An overview of potential feedstocks and process development. Bioresour. Technol. 2013, 135, 386-395. [CrossRef]

54. Cesarini, S.; Pastor, F.I.J.; Nielsen, P.M.; Diaz, P. Moving towards a competitive fully enzymatic biodiesel process. Sustainability 2015, 7, 7884-7903. [CrossRef]

55. Miao, C.; Yang, L.; Wang, Z.; Luo, W.; Li, H.; Lv, P.; Yuan, Z. Lipase immobilization on amino-silane modified superparamagnetic $\mathrm{Fe}_{3} \mathrm{O}_{4}$. nanoparticles as biocatalyst for biodiesel production. Fuel 2018, 224, 774-782. [CrossRef]

56. Filho, D.G.; Silva, A.G.; Guidini, C.Z. Lipases: Sources, immobilization methods, and industrial applications. Appl. Microbiol. Biotechnol. 2019, 103, 7399-7423. [CrossRef]

57. Zhong, L.; Feng, Y.; Wang, G.; Wanga, Z.; Bilal, M.; Lv, H.; Jia, S.; Cui, J. Production and use of immobilized lipases in/on nanomaterials: A review from the waste to biodiesel production. Int. J. Biol. Macromol. 2020, 152, 207-222. [CrossRef] [PubMed]

58. Cipolatti, E.P.; Silva, M.J.A.; Kleina, M.; Feddern, V.; Feltes, M.M.C.; Oliveira, J.V.; Ninow, J.L.; de Oliveira, D. Current status and trends in enzymatic nanoimmobilization. J. Mol. Catal. B Enzym. 2014, 99, 56-67. [CrossRef]

59. Badoei-dalfard, A.; Shahba, A.; Zaare, F.; Sargazi, G.; Seyedalipour, B.; Karami, Z. Lipase immobilization on a novel class of Zr-MOF/electrospun nanofibrous polymers: Biochemical characterization and efficient biodiesel production. Int. J. Biol. Macromol. 2021, 192, 1292-1303. [CrossRef]

60. Colombo, T.S.; Mazutti, M.A.; Luccio, M.D.; de Oliveira, D.; Oliveira, J.V. Enzymatic synthesis of soybean biodiesel using supercritical carbon dioxide as solvent in a continuous expanded-bed reactor. J. Supercrit. Fluids 2015, 97, 16-21. [CrossRef]

61. Pollardo, A.A.; Lee, H.S.; Lee, D.; Kim, S.; Kim, J. Effect of supercritical carbon dioxide on the enzymatic production of biodiesel from waste animal fat using immobilized Candida antarctica lipase B variant. BMC Biotechnol. 2017, 17, 70. [CrossRef]

62. Poppe, J.K.; Fernandez-Lafuente, R.; Rodrigues, R.C.; Ayub, M.A.Z. Enzymatic reactors for biodiesel synthesis: Present status and future prospects. Biotechnol. Adv. 2015, 33, 511-525. [CrossRef]

63. Helwani, Z.; Othman, M.R.; Aziz, N.; Fernando, W.J.N.; Kim, J. Technologies for production of biodiesel focusing on green catalytic techniques: A review. Fuel Process. Technol. 2009, 90, 1502-1514. [CrossRef]

64. e Silva, W.C.; Freitas, L.; Oliveira, P.C.; de Castro, H.F. Continuous enzymatic biodiesel production from coconut oil in two-stage packed-bed reactor incorporating an extracting column to remove glycerol formed as by-product. Bioprocess. Biosyst. Eng. 2016, 39, 1611-1617. [CrossRef]

65. Fidalgo, W.R.R.; Ceron, A.; Freitas, L.; Santos, J.C.; de Castro, H.F. A fluidized bed reactor as an approach to enzymatic biodiesel production in a process with simultaneous glycerol removal. J. Ind. Eng. Chem. 2016, 38, 217-223. [CrossRef]

66. da Silva, C.; Oliveira, J.V. Biodiesel production through non-catalytic supercritical transesterification: Current state and perspectives. Braz. J. Chem. Eng. 2014, 31, 271-285. [CrossRef]

67. Deshpande, S.R.; Sunol, A.K.; Philippidis, G. Status and prospects of supercritical alcohol transesterification for biodiesel production. WIREs Energy Environ. 2017, 6, 252. [CrossRef] 
68. Dehghan, L.; Golmakani, M.T.; Hosseini, S.M.H. Optimization of microwave-assisted accelerated transesterification of inedible olive oil for biodiesel production. Renew. Energy 2019, 138, 915-922. [CrossRef]

69. Milano, J.; Ong, H.C.; Masjuki, H.H.; Silitonga, A.S.; Chene, W.H.; Kusumo, F.; Dharma, S.; Sebayang, A.H. Optimization of biodiesel production by microwave irradiation-assisted transesterification for waste cooking oil-Calophyllum inophyllum oil via response surface methodology. Energy Convers. Manag. 2018, 158, 400-415. [CrossRef]

70. Ding, H.; Ye, W.; Wang, Y.; Wang, X.; Li, L.; Liu, D.; Gui, J.; Song, C.; Ji, N. Process intensification of transesterification for biodiesel production from palm oil: Microwave irradiation on transesterification reaction catalyzed by acidic imidazolium ionic liquids. Energy 2018, 144, 957-967. [CrossRef]

71. Pukale, D.D.; Maddikeri, G.L.; Gogate, P.R.; Pandit, A.B.; Pratap, A.P. Ultrasound assisted transesterification of waste cooking oil using heterogeneous solid catalyst. Ultrason. Sonochem. 2015, 22, 278-286. [CrossRef] [PubMed]

72. Tan, S.X.; Lim, S.; Ong, H.C.; Pang, Y.L. State of the art review on development of ultrasound-assisted catalytic transesterification process for biodiesel production. Fuel 2019, 235, 886-907. [CrossRef]

73. Directive 2009/28/EC of the European Parliament and of the Council of 23 April 2009 on the Promotion of the Use of Energy from Renewable Sources and Amending and Subsequently Repealing Directives 2001/77/EC and 2003/30/EC. Available online: https: / / eur-lex.europa.eu/LexUriServ /LexUriServ.do?uri=OJ:L:2009:140:0016:0062:en:PDF (accessed on 2 November 2021).

74. Ravindra, P.; Saralan, S.; Abdulla, R. LCA studies for alkaline and enzyme catalyzed biodiesel production from palm oil. Adv. Biol. Chem. 2012, 2, 341-352. [CrossRef]

75. Marcia, C.S.D.; Hugo, G.D.V.; André, F.Y.; Fernando, L.P.P.; Andrea, M.S. Life cycle assessment of biodiesel produced by the methylic-alkaline and ethylic-enzymatic routes. Fuel 2017, 208, 329-336.

76. Peñarrubia Fernandez, I.A.; Liu, D.-H.; Zhao, J. LCA studies comparing alkaline and immobilized enzyme catalyst processes for biodiesel production under Brazilian conditions. Resour. Conserv. Recycl. 2017, 119, 117-127. [CrossRef] 